\title{
STRIKES AND STRIKE-BREAKING IN NORTH-EAST ENGLAND, 1815-44: THE ATTITUDE OF THE LOCAL PRESS
}

The effectiveness of the strike weapon in early-nineteenth-century England depended in some measure upon the response of public opinion. Obviously the state of trade and the relative cohesion and determination of masters and men were more significant factors, but the attitude of non-participants could not be discounted. The readiness of civil and military authorities to intervene, the reaction of the general public to requests for contributions to relief funds, the willingness of politicians to contemplate changes in the laws concerning combination: all these were influenced by the state of public opinion. It would be an oversimplification to regard "public opinion" and "newspaper opinion" as synonymous. The platform, the pulpit, the placard and the popular song were other means of public expression, not that they necessarily provided a complete or reliable guide to the public mind. Nevertheless the newspaper, particularly in the nineteenth century, was in an advantageous position to influence the response of the public to current controversies.

At various times during the nineteenth century, working men could rely upon certain newspapers to give sympathetic coverage of their struggles with employers. The unstamped papers of the 1830 's and the Bee-Hive of the sixties and seventies are obvious examples. These were essentially "fringe" newspapers, however, not the normal readingmatter of the general newspaper-buying public. What impression was this public given of contests between capital and labour? In particular, was the politically radical press more likely than other branches of the press to identify with working people in their economic struggles?

Newcastle upon Tyne provides a good centre for examining this question. In 1815 it was the home of three newspapers, the Newcastle Courant, the Newcastle Chronicle and the Tyne Mercury, representing respectively the views of tories, whigs and moderate radicals. It is perhaps an oversimplification to append the label "tory" to the Courant. Edward Walker, its proprietor between 1796 and 1831, never 
introduced an editorial column, and the paper was read by country whigs as well as tories. The Courant's basic toryism, however, can be ascertained from its resentment at Wellington's introduction of Roman Catholic emancipation, and its reaction to the advent to power of the whigs in 1830, when it showed most affinity to the ideas of the ultratories. ${ }^{1}$ As the oldest newspaper published north of the Trent, it had an established circulation, amounting to about 3,000 copies weekly in the early 1830 's, rising to over 4,000 during the vigorous proprietorship of John Blackwell from July 1832. Blackwell voted in favour of the whig-liberal candidates in Newcastle in the general election of 1837, but prided himself on editing a newspaper which stood "above party" and which did not "dwell upon irritating topics". ${ }^{2}$ The Chronicle was more openly partisan, embodying the whig politics of its conductors, Mrs Hodgson and her sons Thomas and James, who succeeded to full control of the paper on their mother's death in September 1822. The Chronicle's weekly circulation was then about 2,000 copies, rising to nearly 3,000 in the late 1830's.

The Tyne Mercury, founded by John Mitchell on 1 June 1802, was ahead of its local rivals in developing a distinct editorial column. Its circulation was approximately 1,500 copies weekly during the closing years of John Mitchell's editorship and the early years of that of his son William Andrew Mitchell, who succeeded to the position on his father's death in 1819. W. A. Mitchell was a founder-member of the Northern Political Union in 1831-32, secretary of the Newcastle Mechanics' Institution from 1833 and a member of the reformed town council from 1836 to 1843 . In the latter capacity he was joined by John Blackwell of the Courant, who later became an alderman, and by James Hodgson of the Chronicle, who became mayor of the town in 1841 and again in 1851. The Mitchells and the Hodgsons were members of the Reverend William Turner's Unitarian Chapel, the spiritual meeting-place of much of the local intelligentsia in this period. The Mercury was more forthright than the Chronicle in its advocacy of constitutional reform. For example, an editorial welcoming various tax concessions in 1822 observed:

"We are grateful for the remission of taxes, but the tax-eating machine - the system that works well for those that do ill, the unreformed channels, the uncleaned common sewers of patronage and corruption, the general power of buying support miscalled 'the influence of the crown', the unaltered House of Commons deformed by the system of rotten-borough misrepresentation

1 Courant, 7 March 1829 and 27 November 1830.

2 Ibid., 27 December 1844. 
[...] - all these remain, and as long as this is the case, we may be better or worse, but we shall never be as we ought."1

Editorials such as these establish the Mercury's claim to be regarded as a radical newspaper in political matters. But where did the Mercury and its local rivals stand on industrial and economic questions? Three case-studies of industrial disputes occurring in the period 1815-32 should provide an answer. This will be developed by a discussion of the Mercury's general standpoint during W. A. Mitchell's editorship, which ended in 1843. As a postscript, some attention will be given to the brief and intriguing interlude under William Fordyce, before the Mercury terminated in 1846.

The prosperity of Tyneside in this period depended to a considerable extent upon the industrial trinity of coal, keels and ships. The miners, keelmen and seamen were three links in the chain between the coalface and the London consumer. Disruption of any stage in the process soon brought the whole enterprise to a standstill, whether the pitmen ceased hewing, or the keelmen stopped ferrying the coals down the Tyne, or the seamen in the colliers refused to set sail. All these three kinds of stoppage occurred within the period 1815-32.

The Napoleonic Wars had been a time of prosperity for those seamen who managed to avoid impressment. Manning-levels became less generous, but wage rises made up for this. After the war, the owners attempted to return towards pre-war wage-rates, without a compensating restoration of the old manning-levels. The return of demobilised sailors aggravated the situation. On 4 September 1815, the seamen began preventing the departure of local coasting vessels, and on 7 September they demanded that the owners should cease to employ foreign seamen and that they should accept a scale of five men and a boy for every hundred tons, at a rate of five guineas per London voyage. The demand concerning foreign seamen was implicitly supported by the Courant, which quoted in its "Marine Intelligence" column the Act of 34 George III, c. 68, requiring all coasting ships to be wholly and solely manned by British subjects, or by foreign seamen who had done three years' service in the Royal Navy, within six months of the termination of hostilities. The owners soon conceded this point and offered to pay $£ 5$ per voyage. They also declared their readiness to allow local insurance assessors to rule on the safety of their manning, but they flatly rejected the manning-scale proposed by the seamen. In this the owners had the unanimous support of the local press. The Chronicle considered the owners' case to be "self1 Mercury, 4 June 1822. 
evident", ' the Courant thought the seamen "misguided", 2 and John Mitchell published a signed editorial addressed "to the seamen of Newcastle, North and South Shields, Sunderland, and all other ports within the circulation of this paper". ${ }^{3}$

Mitchell began in conciliatory fashion, coming forward as an advocate of the oppressed, a friend of the seamen and a sympathiser with their misfortunes. But the men must understand that their demands were bound to ruin their employers and thereby themselves. No commercial venture could afford the wage and manning levels prevailing in naval supply-ships, which had been financed by wartime taxation. In any case, it was "highly reprehensible" of the men to seek to dictate manning levels. Nor could their association be condoned for this end, although it was allowable "if it were upon rational principles of providing in case of need for the necessities of your fellow seamen". Their present conduct was "against every established rule of justice in society". Rather, those in work should contribute from their wages to their unemployed brethren, who could also help themselves by going fishing. The editorial concluded with the comforting information that there was a ready market for salted fish in Catholic countries. This issue also contained an advertisement in which the seamen stated their own case: evidence that the seamen's leaders were alive to the value of having public opinion on their side.

A fortnight later, Mitchell published another signed editorial, expressing his "grief and consternation" that the seamen had disregarded his advice. The tone was now more shrill. "Infatuated men! Whither would your imprudence lead you?" Mitchell accused the strikers of compelling others to join them who would be willing to work, and of putting "a stop to industry and labour of almost every kind". They should accept the concessions offered by the owners and abandon their demand about manning. The seamen retaliated by publishing an amusing piece of propaganda, the Seamen's Chronicle, which gave an Old-Testament-style account of the origins of the strike. ${ }^{4}$ The editor of the Mercury was depicted as a barking dog who had been effectively muzzled by the seamen. Mitchell's response was a more plaintive editorial on 17 October affirming his sympathy for the men in their distress, but pointing out that others were distressed too. He adduced the classical argument that the seamen had embarked upon their particular calling of their own volition, and should not impoverish the community if the terms of employment were not to

1 Chronicle, 23 September 1815.

2 Courant, 30 September 1815.

3 Mercury, 19 September 1815.

4 There is a copy in the Central Reference Library, Newcastle. 
their satisfaction. Mitchell reminded the men that the columns of his newspaper remained open to them.

"For I solemnly promise that with the small expense of the advertisement duty, only three shillings and sixpence (which you must in fairness defray) your reply of a length equal to either of my addresses to you shall have a place in the next number of the Tyne Mercury."

The issue of the following week did not in fact contain a reply from the seamen, but it was too late in any case for the men to appeal to public opinion. On 21 October a combined operation of special constables, naval seamen, marines and troops cleared the blockade of the Tyne and broke the strike. The longer the stoppage had continued, the more hostile the local press had become. The Courant claimed that the seamen's ranks had been swelled by non-seafarers and troublemakers: "Several journeymen tailors, some coachmen, and other surreptitious turbulent characters, from the Nore mutiny, have been found amongst them, living on forceful contributions." 1 The Chronicle supported the intervention of the authorities, although hoping that this could be effected "in an amicable way". ${ }^{2}$ The Mercury's editional of 31 October drew the moral that, should a similar situation recur, "a prompt and vigorous interference of the magistracy can alone be calculated either to preserve the peace of society or to protect the lives and property of individuals". Of the three local papers, the Chronicle dealt with the strike in the most moderate language; indeed, it criticised the London press for sensationalism.

"The late unhappy circumstances appear to have excited a great dread and anxiety in other parts of the country, but particularly in London, where the several newspapers, with a culpable eagerness, have for the last week daily blazened forth all the particulars they could glean of the proceedings, as if the late combination had been some formidable insurrection, threatening injury to the state. [...] This is certainly going too far."3

This episode contains evidence both of the significance and insignificance of newspaper opinion in influencing the course of the dispute. Clearly both sides saw the value of inserting advertisements in the local press. The editor of the Mercury was, in addition, given the dubious compliment of a mention in the seamen's own "newspaper".

1 Courant, 14 October 1815.

2 Chronicle, 21 October 1815.

3 Ibid., 28 October. 
And although the seamen extracted substantial concessions from the owners in the early stages of the dispute, the failure of the prolonged stoppage sustained the pessimistic viewpoint of the editorial columns. On the other hand, there is evidence of financial support for the seamen from the general public. ${ }^{1}$ The military authorities were manifestly reluctant to intervene, ${ }^{2}$ and the Home Secretary only ordered the forcible opening of the Tyne when the strike had entered its sixth week. Indeed, the impatience of the radical Mercury with the hesitancy of the authorities is a revealing corrective to the stereotype of an oppressive government in conflict with the journalistic champions of the people.

The Tyne keelmen had several battles with their employers during the early nineteenth century. The strikes of 1809 and 1819, each lasting three weeks, secured various gains for the keelmen. ${ }^{3}$ The latter dispute, however, revealed the inability of keelmen to prevent the utilisation of riverside drops and spouts for loading colliers directly, eliminating the need for keels. The threat of new loading-techniques was particularly felt by keelmen operating downstream of the Tyne bridge. Their above-bridge brethren were protected by the inability of colliers to penetrate up-river. The ten-week strike of 1822, ostensibly in protest against wage-cutting, really derived from the keelmen's anxiety about the spouts. Sympathetic news-coverage was thus important to the keelmen if they were to be able to maintain solidarity and avoid antagonising the public by the stoppage.

The initial response of the Chronicle and the Mercury was one of neutrality, although the Courant was quick to cast aspersions upon the keelmen: "Some of them are stated to be wandering about the country in the character of sturdy beggars, and it is reported that others have made free with the turnip and potato fields within their reach."4 Nor did the Courant place much credence in the keelmen's Address, which it considered to be "full of misrepresentations" and designed to arouse unmerited sympathy for the keelmen. They must face the fact that new techniques were making their occupation increasingly outmoded. The Mercury soon revealed its antipathy to the stoppage, repeatedly accusing the keelmen of being in breach of contract. It disregarded the point that the owners had first broken the 1819

1 Courant, 28 October 1815.

2 N. McCord, "The Seamen's Strike of 1815 in North-East England", in: Economic History Review, Second Series, XXI (1968), p. 131.

'D. J. Rowe, "The Strikes of the Tyneside Keelmen in 1809 and 1819", in: International Review of Social History, XIII (1968); N. McCord, "Tyneside Discontents and Peterloo", in: Northern History, II (1967).

- Courant, 11 October 1822. 
agreement by attempting wage reductions. ${ }^{1}$ The Chronicle lamented that the keelmen's "obstinacy will be a source of much distress to themselves, and of injury to the best interests of this distict". ${ }^{2}$ Efforts to break the strike by moving keels downriver were forcibly prevented by the keelmen at Scotswood.

This provoked a belligerent editorial in the Mercury, criticising the owners for their weakness in not destroying the keelmen's bonds, as they had threatened to do, and accusing the civil and military authorities of failing to prevent acts of violence and the obstruction of the river. ${ }^{3}$ The authorities did put on a greater show of strength, using naval sailors, with military protection. At first the keelmen held firm, and the Mercury suggested that some small concession from the owners might enable the men to save face and return to work. By the following week, however, the Mercury was again arguing that the keelmen were expediting their own destruction by forcing the owners to have greater recourse to spouts and steam haulage. The Chronicle and the Courant reiterated the latter point, both adding that steam boats were now towing down keels from above the bridge. ${ }^{4}$ Thus, far from protecting the livelihood of below-bridge men, the strike now threatened the security of above-bridge men also. This consideration, together with the increasing forcefulness of the authorities, eroded the determination of the strikers. Some of the above-bridge men returned to work on 5 December, and the strike collapsed two days later. Once again there is evidence of public sympathy for the keelmen and their families, as indicated by a report in the Courant.

"On Saturday night last, numbers of the keelmen and their wives were begging in this town; and received from many thoughtless shopkeepers a premium for their unlawful conduct; which was wasted by some of them in the public houses on the Quay." 5

This defeat marked the turning point in the keelmen's strategy of using industrial sanctions to preserve their traditional occupation. They turned instead to the law-courts, retaining Henry Brougham to plead the case that the spouts were obstructive to navigation. The superior wisdom of the judicial bench found that this allegation was valid, but that the use of spouts should continue, as trade benefited

1 D. J. Rowe, "The Decline of the Tyneside Keelmen in the Nineteenth Century", in: Northern History, IV (1969), p. 113.

${ }^{2}$ Chronicle, 26 October 1822.

s Mercury, 5 November 1822. The "bond" was the yearly agreement setting out the keelmen's conditions of service.

4 Chronicle, 23 November 1822; Courant, 23 November 1822.

${ }^{5}$ Courant, 7 December 1822. 
thereby. As with the outcome of the seamen's strike of 1815 , the keelmen's defeat is to be explained mainly by economic realities, sustained by the prevailing power-structure. The struggle was rendered even more one-sided, however, by the radical Mercury's encouragement of firm action by the authorities and its insistence upon the selfdefeating nature of the men's withdrawal of labour.

The successful strike in 1831 of Thomas Hepburn's Pitman's Union of the Tyne and Wear caused the Mercury to reflect upon the changed relationship between the coalowners and the miners: "The master has lost his authority, and the servant will not work longer than he thinks proper, however, urgent the demand for his services may be."1 The Mercury gloomily predicted that another battle was looming, and on 27 December it printed a report on the intimidation of blackleg lead-miners at Waldridge colliery, near Chester-le-Street. It claimed that the pitmen were exercising a "tyranny" over their employers. They had broken their agreements and were preventing the leadminers, whose wages were lower than the pitmen's, from doing work which the pitmen would not themselves do. Nonetheless the report ended with the pious thought: "God forbid that we should favour the oppression or ill-treatment of the colliers." In 1832 the struggle was renewed, as the Mercury had feared. A lengthy editorial on 27 March reviewed the Mercury's position. In 1831 the men had genuine grievances, which the paper rejoiced to see removed, although it regretted the manner in which the dispute was ultimately settled. "The gain was all on the side of the servants at the expense of the masters." But now nemesis was about to overtake the men. Their denial of labour to their employers had brought about the recruitment of lead-miners in their place. The pitmen should therefore avoid further hardship by a "timely submission".

The hostile tone of the Mercury was in sharp contrast to the balanced and even sympathetic manner in which the Chronicle and the Courant reported on the pitmen's grievances. ${ }^{2}$ The Courant commended the peaceable and orderly behaviour of the men at the meeting on 3 March, in which the leaders explained their differences with the owners. The report stressed that the men were anxious to preserve the union, which had organised relief for them during the recent cholera outbreak, whereas some of the owners, resenting the union's objection to the employment of lead-miners, had told their men to choose between the union and their employment. The Courant was at this time in the hands of Charles Henry Cook, following the death of Edward Walker in 1831, and this may have accounted for the gentler tone of the reporting.

1 Mercury, 18 October 1831.

${ }^{2}$ Chronicle, 10 March 1832; Courant, 10 March 1832. 
The Chronicle, however, remained under the control of the brothers Hodgson, and their coverage of the dispute was factual and fair. On 5 May the Chronicle published an advertisement from the Hetton pitmen, giving their version of their differences with the owners, to counter the coal company's version as published in the Mercury. By this date, the Courant's attitude was beginning to harden. It considered the introduction of outside labour and the eviction of strikers' families to be the unavoidable outcome of the men's "obstinacy". 1

The Courant's tone remained mild, however, compared with the Mercury's repeated denunciation of what it considered to be the arrogant folly of the men's leaders. ${ }^{2}$ The eviction of strikers and their families from colliery cottages at Friar's Goose, near Gateshead, provoked serious disturbances. The Mercury appreciated the anguish felt by the ejected occupants, and by pitmen who saw their jobs going to outsiders. But a fortnight had passed since their yearly bond had expired, and they had had "fair, nay, liberal wages offered to them by the coalowners". 3 The Mercury understood the matter clearly:

"The whole question has appeared to us from the first to be a simple matter of contract. The coalowners want labour; the pitmen have it to sell: if they ask too high a price, surely the coalowners are as much at liberty to buy it elsewhere as the pitmen are to sell it elsewhere."

The strike was ruining local trade and leading to beggary and crime. "The coalowners, we are rejoiced to hear, have resolved to petition the legislature to devise some means to put an end to such a state of things; it is high time that it should cease."

The Chronicle, by contrast, was at pains to avoid exploiting the Friar's Goose affray by denigrating the participants. The concluding paragraphs of its account were carefully impartial.

"How this lamentable affair commenced it is very difficult to ascertain; on the one hand it is represented as a most determined unprovoked attack, whilst on the other it is said to have arisen from some unnecessary harshness on the part of the police, particularly to some of the women. We were in hopes that the investigation before the Magistrates would have thrown some light upon the affair, and we accordingly sent a reporter to attend it: but no public examination was then entered into, the men were

1 Courant, 5 May.

${ }^{2}$ One wonders what the Mercury would have thought of the Post Office's commemorative stamp, April 1976, which shows Thomas Hepburn alongside the head of the Sovereign.

${ }^{3}$ Mercury, 8 May 1832. 
merely identified by the police as having been present, and the depositions of the constables, which had been previously drawn up, were read over to them, without any evidence being gone into, or any witnesses examined on the part of the men. We therefore consider it would be unfair to enter into any detail of ex parte statements or hearsay reports, which might be calculated to create an unjust prejudice against persons committed for trial on so serious a charge." 1

As the strike dragged on through the summer, the prospects for the men and their union became increasingly gloomy. The Courant, both before and after its transference to the ownership of John Blackwell in July, pointed out that imported labour was enabling production to continue, without the aid of the striking pitmen. Moreover, the pitmen who had remained in work, to supplement the strike funds, were increasingly unable to maintain their out of work brethren. At the end of September the strike collapsed, and with it Hepburn's union. The Mercury's epitaph on the strike was to rejoice at the break up of the union and to hope that the pitmen would not again become "the dupes of a set of designing knaves". ${ }^{2}$

It is apparent from the three foregoing case-studies that men in conflict with their masters in this period could rarely expect anything more than neutrality from the newspapers of Newcastle upon Tyne. More pointedly, there is no evidence that the paper which espoused the popular cause in politics, as did the Mercury, felt any obligation to champion working people in their industrial struggles. Indeed, of the three newspapers examined, the Mercury emerges as consistently the most antipathetic to the use of the strike weapon. The Courant depicted the seamen as having been infiltrated by troublemakers, and the keelmen as engaged upon a futile struggle, but it dealt fairly with both sides in the 1832 pitmen's strike. The Chronicle was consistently the most impartial in its coverage. The Mercury, on the other hand, was noticeably quick to call out for intervention by the civil and military authorities, the very establishment which at other times it denounced for being so unrepresentative and expensive.

It is also interesting to note that, although two of the three disputes occurred during the period when the Combination Acts were on the statute book, a fairly close examination of the local press has yielded no reference to these enactments. There are instances when the strikers, by the mere fact of being on strike, were accused of indulging in

1 Chronicle, 12 May 1832.

${ }^{2}$ Mercury, 25 September 1832. 
illegality, but the context is clearly that of alleged breach of contract, not the flouting of statute law. The seamen, keelmen and miners belonged to tightly-knit communities, and made a vital contribution to the prosperity of the region. The arduous and sometimes dangerous nature of their work predisposed a significant section of the general public to feel sympathy for them in times of trouble. In these circumstances it would have been maladroit of the authorities to exacerbate a dispute by invoking the laws against combination, at any rate while there was the prospect of a quick settlement. In the case of a prolonged strike, with the usual accompanying features of assaults upon blacklegs and an increase in beggary and petty theft, the threat to law and order could be utilised to justify intervention by the authorities, regardless of the Combination Acts.

There remains the task of explaining the attitude of the Mercury. From its inception it had placed itself in the vanguard of political reform, proclaiming the cause of the people against the ruling oligarchy. Why then was it so reluctant to take the side of working men when they came into conflict with their employers? An answer can be found by examining other leading articles in the Mercury during this period. In essence the paper was a vehicle for the doctrines of political economy. The fullest statement of its position was contained in an editorial on trade unions in the issue of 10 December 1833. The writer's attitude was doubtless influenced by the contemporaneous general union movement, from which the Grand National Consolidated Trades' Union emerged. The Mercury considered it to be quite legitimate for both sides to combine in order to bargain about wage-rates, and to refuse labour or employment if the terms were unacceptable. But trade unions had long exceeded this proper function.

"Some of them have fixed their own hours of labour; others have said 'You shall not have more than such and such a number of apprentices;' others 'You must have so many journeymen,' or 'If you take on that man we will one and all quit your employment."

Others insist that day-work should replace piecework. But these are matters for the judgement of the master: only wages and wage-rates are properly the subject for collective bargaining. As for the "insane" notion that "those who labour ought to be the possessors of all the land and treasure of the country", this was the kind of nonsense to be found in the "cheap unstamped trash" which was so widely published. Here too was the source of the current "mania for trades' unions", which had been further inflamed by recent political excitement (in which, it should be remembered, the Mercury's editor had actively 
participated as an advocate of the Reform Bill.) The best way to mitigate the mania was not by legislation, which would be too complicated to enforce, but by "caution, firmness, and moderation on the part of the masters, frequent meetings of the masters with the men, and $[\ldots]$ a systematic and universal scheme of cheap national education".

The Mercury, however, was prepared on occasion to soften its commitment to classical economics. It supported Sadler's Bill in 1832 to regulate the labour of children in factories, and put forward an argument which applied to adults as well as children. If a manufacturer pleaded that he had a right to do what he wished with his own, this could be accepted only where his machinery was concerned, not where it affected the life and limb of his employees. "Factory slavery", declared the editiorial, "is quite as cruel as the slavery of the West Indies." In 1826 the Mercury had advocated a scheme of public works as a means of alleviating unemployment. Although it gave steady support to the New Poor Law, the Mercury rebuked Lord Brougham for having allegedly declared that charity to the aged and the infirm was against all principle. On this matter, said the Mercury, "We are opposed to his lordship altogether."2

In May 1843 the Mercury's forty-year connection with the Mitchell family came to an end. The new proprietor, William Fordyce, was a local printer who, at an earlier stage in his career, had published a prospectus for a new weekly newspaper, the Northumberland Herald; or, the Northern John Bull. This can be dated, by context, in the spring of 1832 and it contained the following pledge:

"Our columns will be ever open to expose the abuses in the coal trade: that most serious of all its evils, the combination of the coal owners, deserves particular notice; [...] the distress which such combination brings upon the great body of colliers in this neighbourhood - the large and powerful meetings which such distress creates of the men who are the very strength and sinew of the north countrie, are evils and dangers that require the earliest opportunity to eradicate."

The Herald faded into oblivion, but now Fordyce had the opportunity to give the miners the sympathetic coverage which his abortive earlier venture had promised. Certainly the Mercury under Fordyce was highly critical of the New Poor Law and denunciatory of the abuse of child labour in factories. An editorial on "the Factory

1 Ibid., 17 July.

2 Ibid., 29 July 1834. 
Question" echoed Thomas Carlyle in its condemnation of "mammonism".

"The truth is, and a sad and most disgraceful truth it is, that in England, for many years, everything has been computed in money. No value has been recognised either by the legislature, by the political press, or by economists in or out of parliament, but a money value. Morality, religion, common humanity, and common sense, have been cast aside; and the Juggernaut of mammon set up as a sole object of national worship." 1

Yet when confronted by an industrial dispute, the Mercury reverted to its position during the Mitchell era. The outbreak of the miners' strike of 1844 was bemoaned as a "lamentable and ill-judged state of affairs". ${ }^{2}$ Nor could the strikers' morale have been helped by the editorial of 28 May, which claimed:

"the sensible portion of the pitmen are becoming convinced of the hopelessness of the present strike: indeed, if the interested leaders in their pay were put out from amongst them, there cannot be a doubt that this deluded body of men would immediately resume their employment, on the liberal terms proposed by the Coal-owners."

At the end of 1845 Fordyce sold the Mercury to P. S. Macliver and T. N. Cathrall, who kept it alive for only a few weeks before absorbing it into their new weekly paper, the Newcastle Guardian. The new publication put its faith in the classical liberal formula of free trade and cheap government.

If the Mercury can serve as a model for some, at least, of the moderately radical newspapers published in provincial centres, it is evident that such newspapers can have provided little aid and comfort to emergent trade unions. The use of the strike weapon was repeatedly deplored; the civil and military authorities were encouraged to intervene; the use of blackleg labour was defended; and the tenets of political economy were adduced to point out to the strikers the impropriety of telling their employers how to run their businesses and the futility of persevering in a prolonged trial of strength when the odds were so clearly against them.

The temptation must be avoided, however, of rushing to accuse the conductors of the Mercury of adopting double standards in their coverage of political and industrial questions. There is no reason to doubt the genuineness of John and William Andrew Mitchell's con-

1 Ibid., 30 April 1844.

2 Ibid., 16 April. 
viction that the strike weapon injured the wielders as much as those against whom it was taken up. Especially was this the case in the prolonged disputes examined here, when each successive week made the prospect more gloomy. Indeed, given the existing disposition of political and economic power, the Mercury's repeated advice that the strikers should return to work was sound, if dispiriting. The vehemence with which this advice was sometimes given, and the tendency to overemphasise the threat to public order from the strikers, may likewise be attributed to the genuine anxiety of the Mercury's conductors lest the situation should deteriorate into an open conflict in which all classes would suffer.

Nevertheless, while not impugning the journalistic integrity of the Mitchells or their local contemporaries, one must observe that their survival did depend to some extent upon the enunciation of views that were in harmony with the sentiments of their readers. A provincial newspaper published during the period when the "taxes on knowledge" were at their peak had to struggle hard to obtain a viable circulation. "Respectable" subscribers accounted for the bulk of the readership, together with the members of news rooms and mechanics' institutes, in which the average keelman or miner would have been sadly out of place. Nor were the industrial classes either the object or the providers of advertising, before the age of mass-marketing and classified small advertisements. Property transactions, public notices, shipping information and shopkeepers' announcements formed the staple content of the advertising columns. It would have been folly to antagonise subscribers and advertisers by forthrightly championing the men against their masters, particularly in cases of prolonged strikes which were damaging local trade. When the men possessed the franchise and enjoyed the means and opportunity to become regular newspaper readers, a provincial paper could take their side against the employers without jeopardising either its commercial prospects or the political ambitions of the proprietor. The success of Joseph Cowen's Newcastle Daily Chronicle in the 1870 's and 1880 's sustains this view. ${ }^{1}$ It was a very different situation in the period of the Mercury.

In the light of the evidence discussed here, it is apparent that no simple stereotype will suffice to comprehend the complexities of industrial conflict and political allegiance in the early nineteenth century. The whig Nerecastle Chronicle's unemotional coverage of local disputes can perhaps be seen as embodying the pragmatism with which whig politicians approached the challenge of Chartism. Such pragmatism, however, was sadly lacking during the agrarian disturbances of the 1 M. Milne, The Newspapers of Northumberland and Durham (Newcastle, 1971), ch. 3. 
early 1830's. Neither can the views of the Newcastle Courant offer much solace to those who assert the strength of tory paternalism in the era of Oastler and Sadler. The Courant did initially appreciate the viewpoint of the striking pitmen in 1832, however, and in so doing it ceded to the radical Tyne Mercury the first place among Newcastle newspapers for consistency of opposition to the use of the strike weapon. The facile assumption that radical political beliefs would predispose their holder to espouse the cause of organised labour will not stand up to close scrutiny, at least where one important industrial region and its newspapers are concerned. 